\title{
Recent Advances in Research on Terrestrial and Marine Sequences From the Mid-Cretaceous Oceanic Anoxic Events (OAEs)
}

by Reishi Takashima, Pitambar Gautam, and Hiroshi Nishi

The Cretaceous period was a time of greenhouse climates characterized by sea-surface temperatures of at least $15^{\circ} \mathrm{C}$ warmer than today. During the climax of Cretaceous warming, anoxic conditions in the oceans expanded globally, resulting in accumulations of organic-rich sediments (socalled black shales). These events, called Oceanic Anoxic Events (OAEs), occurred at least eight times during the Cretaceous period (Fig. 1). Three important aspects make the study of OAEs so interesting: (a) the OAEs acted as a global thermostat because carbon to a large extent was sequestered in the sediments (black shales) instead of adding to the $\mathrm{CO}_{2}$ content of the atmosphere, (b) the expansion of anoxic conditions in the oceans caused mass extinctions of marine biota, and (c) most hydrocarbon source rocks from the Cretaceous formed under anoxic oceanic environments.

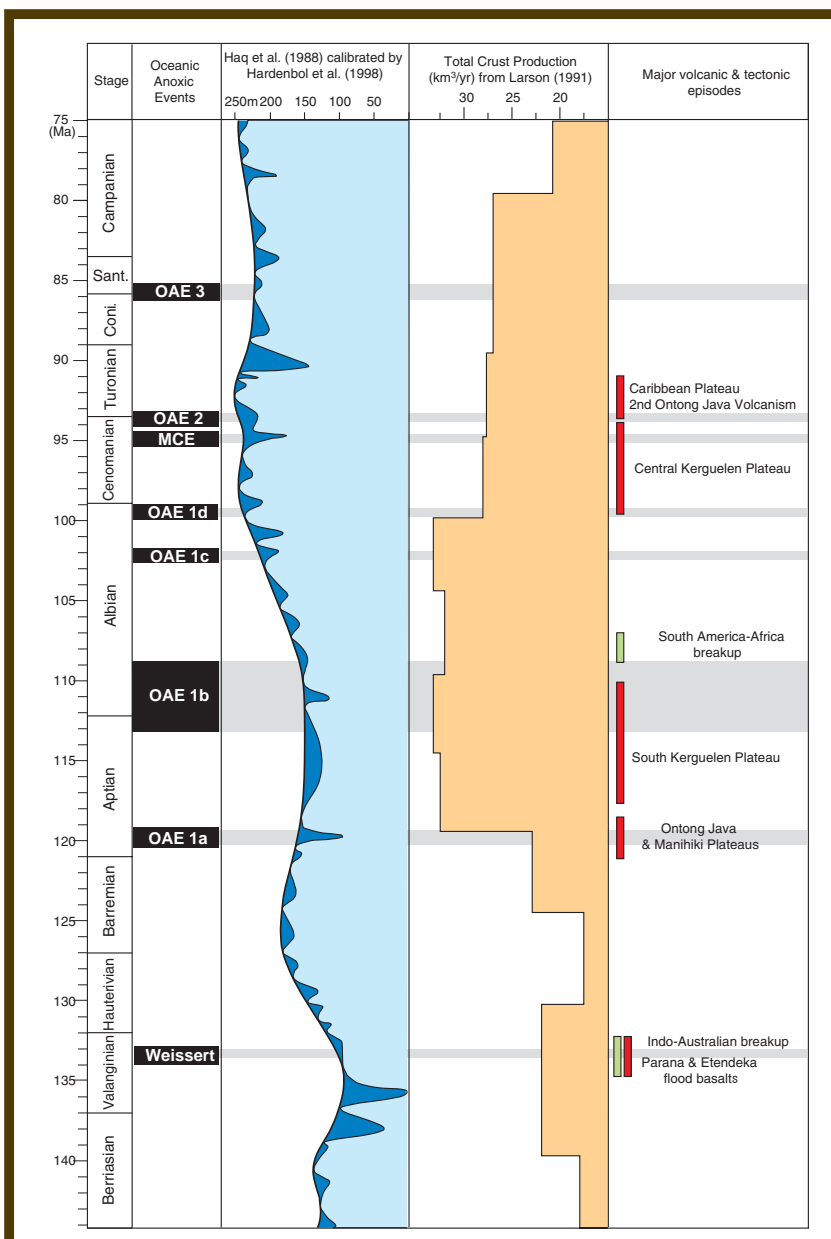

Figure 1. OAE horizons, sea level changes and production rate of the oceanic crust.
The discovery of the Cretaceous OAEs (Schlanger and Jenkyns, 1976) was an important achievement of the Deep Sea Drilling Project (DSDP), and understanding Cretaceous OAEs is one of the major scientific objectives of the extreme climate initiative outlined in the Integrated Ocean Drilling Program (IODP) Initial Science Plan. To support this initiative a symposium entitled "Recent Advances in Research on Terrestrial and Marine Sequences from the midCretaceous Oceanic Anoxic Events (OAEs)" was held at Hokkaido University, Sapporo, Japan during 21-23 September 2005. The symposium was hosted by the $21^{\text {st }}$ Century Center of Excellence (COE) Program for the Neo-Science of Natural History, and was organized by Hisatake Okada (COE program leader) and Hiroshi Nishi. Thirteen talks were given, eight by invited speakers, and eight posters dealt with land and marine OAE sections shown in Figure 2. Discussion of land sections concentrated on two types of regions: (a) those with black shale, such as Umbria-Marche Basin, Western Interior, Northwest German Basin and Vocontian Basin; and (b) those devoid of black shale, such as the AngloParis Basin, Yezo Basin and Great Valley Basin. For regions of the first type, the group discussed results of high-resolution studies on a millimeter to centimeter scale of microfossils and organic and inorganic geochemical analyses. It was demonstrated that the black shales in continental interiors and on the continental margins were deposited during marine transgressions, with individual laminae corresponding to the increased runoff from the land areas. For regions of the second type, attention was paid to the integrated analysis of macro- and microfossil and carbon isotope stratigraphies for identification of the precise horizons of OAE levels. Although fully anoxic environments apparently did not develop in these basins, clear evidence of remarkable faunal turnover, involving various taxa, was shown at the OAE levels. Studies of the marine sections dealt with core data mainly from Blake Nose (ODP Leg 171B) and the Demerara Rise (ODP Leg 207). Both sections have yielded extremely well-preserved calcareous fossils suitable for isotopic geochemical analysis. Oxygen and carbon isotope data on planktic and benthic foraminifers revealed the development of two types of water-column structures during OAEs. The first type, represented by collapse of the vertical structure of the water column caused by abrupt deep-water warming, is recognized in OAE2 and OAE1d. Such OAEs are characterized by increased primary production, drowning of carbonate platforms and worldwide deposition of black shale. The second type corresponds to intensified water-column 


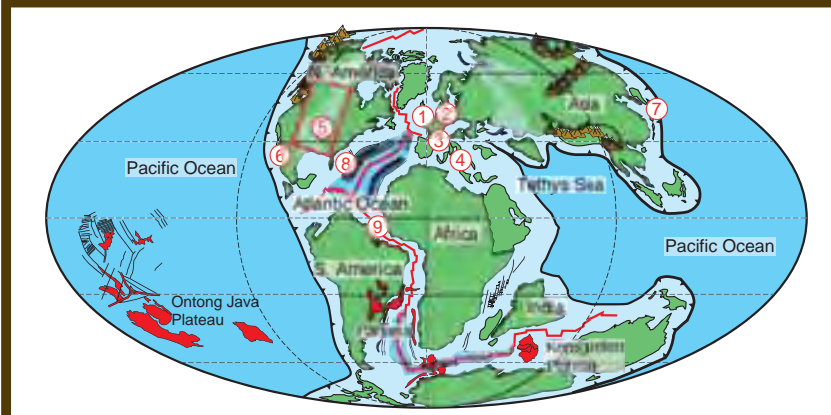

Figure 2. Study areas (presenters) considered during the OAE Sapporo Symposium.

1. Anglo-Paris Basin (A.S. Gale), 2. NW-German Basin (J. Mutterlose), 3. Vocontian Basin (R. Takashima; K. Nagai et al.; K. Okano et al.), 4 Italy (J. Kuroda et al.), 5. Western Interior (M. Leckie et al., B. Sageman et al.), 6. Great Valley (A. Fernando et al., T. Tomosugi et al.), 7. Yezo Basin (H. Ando; K. Kurihara \& F. Kawabe), 8. Blake Nose (B. Huber et al., J. Erbacher et al.), and, 9. Demerara Rise (J. Erbacher et al., A. Bornemann \& R.D. Norris; P.A. Meyers \& J.-G. Yum; A. Forster et al.)

stratification triggered by an increase in the surface water temperature or a decrease in salinity (e.g., Pacquier level of OAE1b).

One question related to OAEs focuses on identifying the factors responsible for the increased runoff observed in the land sections and the warming of surface and deep water observed in marine sections. The emplacements of large igneous provinces (LIPs) are thought to be the most plausible trigger because they occurred contemporaneously with each OAE (Larson, 1991); however, the emplacement positions of LIPs, their depths of eruption, the amount of magma production, and the composition of the magma were highly variable. Moreover, there still are no adequate data that allow scientists to deduce the relationship between the formation of LIPs and development of the anoxic water column in the ocean.

During the concluding session of the symposium, the activities of the IODP and the Japan Drilling Earth Science Consortium (J-DESC) were introduced, and potential IODP drilling sites directed at Cretaceous OAE research were discussed. To understand how the OAEs occurred requires

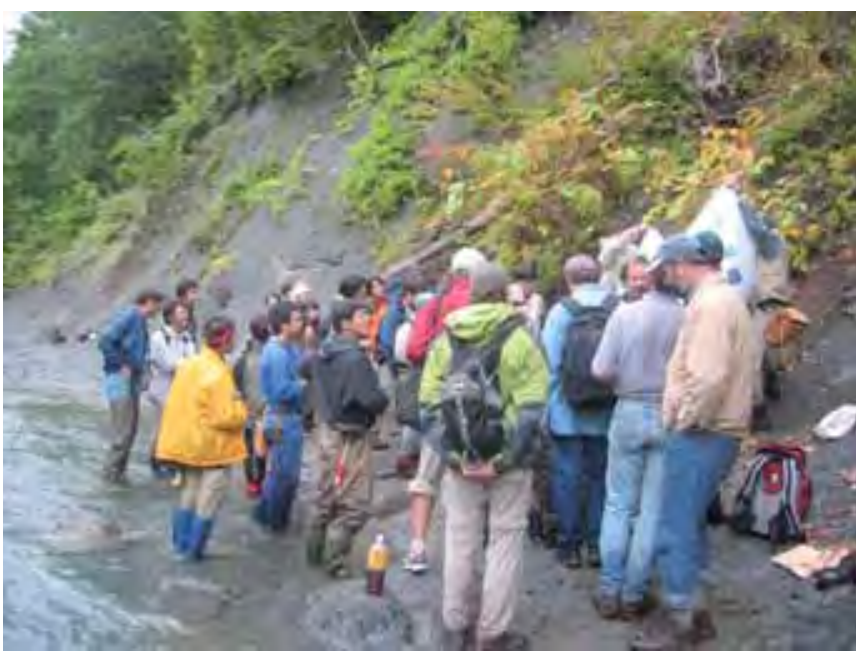

Figure 3. Outcrop of the OAE2 horizon in the Yezo Group, Hokkaido. knowledge of the thermal structure of the ocean during those greenhouse periods. As reliable ocean temperature data for pre-Aptian times and high-latitude regions are still inadequate, these aspects need due consideration in the future. The Falkland Plateau was recommended as the most appropriate target for a future IODP drilling campaign.

The symposium ended with an one-day field trip to the OAE2 section in Hokkaido (Fig. 3). This section bears evidence of a prominent positive excursion in the $\delta^{13} \mathrm{C}$ of organic matter, weakened bioturbation, and occurrence of abundant pyrite, although typical black shale is absent.

Further information about the talks and future directions can be obtained from the links mentioned below.

\section{References}

Haq, B.U., Hardenbol, J., and Vail, P.R., 1988. Mesozoic and Cenozoic chronostratigraphy and cycles of sea-level change. In Wilgus, C.K., Hastings, B.S., Kendall, C. G. St.C., Posamentier, H.W., Ross, C.A., and Van Wagoner,J.C. (Eds.), Sea-Level Changes-An Integrated Approach. Spec. Publ.-SEPM, 42:72-108.

Hardenbol, J., Thierry, J., Farley, M.B., de Graciansky, P.-C., and Vail, P.R., 1998. Mesozoic and Cenozoic sequence chronostratigraphic framework of European basins. In de Graciansky, P.-C., Hardenbol, J., Jacquin, T., and Vail, P.R. (Eds.), Mesozoic and Cenozoic Sequence Stratigraphy of European Basins. Spec. Publ.-SEPM (Soc. Sediment. Geol.), 60:3-13.

Larson, R.L., 1991. Latest pulse of Earth: evidence for a midCretaceous super plume. Geology, 19:547-550.

Schlanger, S.O., and Jenkyns, H.C., 1976. Cretaceous oceanic anoxic events: causes and consequences. Geol. Mijnbouw, 55:179-184.

\section{Authors}

Reishi Takashima, Division of Earth and Planetary Sciences, Graduate School of Science, Hokkaido University, N10 W8, Sapporo 060-0810, Japan, e-mail: rtaka@nature.sci. hokudai.ac.jp

Pitambar Gautam, Graduate School of Science, Hokkaido University, N10 W8, Sapporo 060-0810, Japan

Hiroshi Nishi, Division of Earth and Planetary Sciences, Graduate School of Science, Hokkaido University, N10 W8, Sapporo 060-0810, Japan

Authors are affiliated with the 21st Century COE for "NeoScience of Natural History-Origin and Evolution of Natural Diversity" at Hokkaido University.

\section{Related Web Links}

http://nature.sci.hokudai.ac.jp/index_e.html http://nature.sci.hokudai.ac.jp/symposium/050921/OAESapporo-abstracts.pdf 